\title{
A comparative analysis of nurse and physician characters in the entertainment media
}

\author{
Philip A. Kalisch PhD Professor of History, Politics and Economics of Nursing and Interim \\ Director, Centre for Nursing Research, University of Michigan and Beatrice J. Kalisch RN EdD \\ FAAN Titus Distinguished Professor of Nursing and Chairperson, Parent-Child Nursing, University \\ of Michigan, 609 East Liberty Street, Ann Arbor, Michigan 48108, USA
}

Accepted for publication 11 June 1985

KALISCH P.A. \& KALISCH B.J. (1986) Journal of Advanced Nursing 11, 179-195 A comparative analysis of nurse and physician characters in the entertainment media The results of a large body of research have yielded findings supportive of the view that the mass media have a decisive effect on the formation of public attitudes and behaviours. This study reports the results of a content analysis of 670 nurse and 466 physician characters portrayed in novels, motion pictures and prime-time television series, published or produced from 1920 to 1980 . When compared with media physicians, media nurses were consistently found to be less central to the plot, less intelligent, rational, and individualistic, less likely to value scholarliness and achievement and exercise clinical judgement. Moreover, in television series nurse characters were depicted as valuing service to others and being helpful to patients less, and as being lower in nurturance and empathy than physician characters. An analysis of these data over time points to a steady and unmistakable decline in the mass media entertainment image of nurses while physician characters have remained consistently high or shown improvement. The implications of this image gap are discussed along with the need for image reshaping efforts which might direct public demand for more collegial and productive 'real world' nurse-physician roles and interprofessional relationships.

\section{IMAGES}

Images surround us. There are those we fabricate ourselves, perceptually; and there are those fabricated for us, artistically or commercially. Images are things that represent (re-present) something else. To represent with images is to symbolize, and symbolization is basic to communication. By means of symbols, we enter into processes of communication and exchange with one another. Kenneth Boulding (1956) names the basis for human behaviour the 'image' in order to emphasize that it is 'a subjective knowledge structure', not necessarily reflecting actuality in all of its components. Images are mental representations that influence how people see all aspects of life including health care (King 1979, Nichols 1977, Shorr 1980).

The mass media have an enormous impact on the formation of images, largely on the unconscious level. The dogma of media powerlessness, prevalent in the 1950's and early 1960 's, is no longer tenable. Results of considerable research completed in the last decade lead to the undisputable conclusion that the mass media have a decisive effect on people's conceptions of the world. The mass media influence how children and adults think about the society around them, or in other words, how they form their conceptions of 'social reality'. This conclusion is based both on laboratory experiments and on field studies. Observational learning 
from the mass media, particularly television, has been demonstrated numerous times.

Studies, for example, have shown that the mass media influences attitudes towards products for purchase (Donohue 1975, Caron \& Ward 1975, Ward et al. 1977, Goldberg \& Gorn 1978, Galst \& White 1976, Robertson et al. 1979, Atkin 1978), the importance of material possessions (Churchill \& Moschis 1979, Moschis \& Churchill 1978), drug use (Milavsky et al. 1975, Feingold \& Knapp 1977), family values (Greenberg et al. 1980b, Johnson et al, 1978, Fisher \& Dean 1976), and health behaviours (Breed \& Defoe 1981, Kaufman 1980, Greenberg et al. 1980b, White \& Sandberg 1980). Media portrayals have also been shown to lead to a greater acceptance of aggressive behaviour (Drabman \& Thomas 1974, Thomas \& Drabman 1975, Eron \& Huesmann 1980a, Huesmann et al. 1981). A higher exposure to television violence has been demonstrated to yield increased feelings of fear and mistrust (Gerbner et al. 1978, Gerbner et al. 1979, Bryant et al. 1981).

\section{Mass Media}

The mass media have also been found to promote stereotypic thinking about such groups as women (Haskell 1973, Rosen 1973, Silverman et al. 1979, Seggar 1975, Busby 1974, Henderson \& Greenberg 1980, Lemon 1977, Long \& Simon 1974, Miller \& Reeves 1976, Himmelweit \& Bell 1980, Williams et al. 1981), the elderly (Greenberg et al. 1980a, Aronoff 1974, Petersen 1973, Stoddard 1980, Harris \& Feinberg 1977, Cassata et al. 1980, Kubey 1980, Shinar \& Biber 1978), and minorities (Mapp 1970, Dominick \& Greenberg 1970, Pettit 1980, Bataille \& Silet 1980, Cripps 1977, Northcott et al. 1975, Greenberg 1972, Surlin \& Tate 1976, Meyer 1976, Surlin 1978).

The attitudes moulded by the mass media have been shown to translate into actual behaviour. One of the most heavily researched areas in terms of media influence on behaviour has focused on the issue of violence and aggression. Viewing television has been found to result in an increase in the violent and aggressive behaviour of children and adolescents (Belson 1978, Singer \& Singer 1980, McCarthy et al. 1975,
Williams 1978, Granszberg \& Steinberg 1980, Eron \& Huesmann 1980b, Huesmann et al. 1981, Hartnagel et al. 1975, Greenberg 1975). On the other end of the continuum, studies have demonstrated that the mass media lead to altruistic behaviour (Bryan 1975, Elliott \& Vasta 1970, Rushton \& Owen 1975, Sprafkin et al. 1975, Friedrich \& Stein 1973, Friedrich \& Stein 1975, Friedrich-Cofer et al. 1979, Tower et al. 1979, Loye et al. 1977) as well as friendliness (Gorn et al. 1976, Coates et al. 1976). Furthermore, media portrayals have been linked to increased ability to delay gratification (Yates 1974, Friedrich \& Stein 1973).

Particularly relevant to the study of nurses and physicians in the entertainment mass media are studies which have demonstrated that the mass media influences attitudes about occupational roles (Abel et al. 1981, Seggar \& Wheeler 1973, Jeffries-Fox \& Signorielli 1978). Specific occupations which have been studied in depth include ministers (Worden 1962), teachers (Gerbner 1964), newspapermen (Barris 1976), and physicians (Cousins 1982, De Bakey 1964, Ceccio 1978, Cameron 1973, Trautman 1981, Norris 1969, Silvetter 1967). Adults who view a large amount of health care drama on television, for example, have been found to have more faith in physicians' abilities to help them than those who view none or very few of these dramatizations (Volgy \& Schwartz 1980, Gerbner et al. 1982). Young children who are heavy viewers have also been found to have attitudes about the health care world similar to television depictions (Arenstein 1974, McLaughlin 1975a, 1975b).

\section{No systematic study}

No systematic study of the portrayal of nurses in the entertainment mass media had been undertaken prior to the present work. Selected results from this research have been previously reported (Kalisch et al. 1980, Kalisch \& Kalisch 1981, Kalisch et al. 1981, Kalisch \& Kalisch 1982, Kalisch et al. 1982a, 1982b, Kalisch \& Kalisch 1983, Kalisch et al. 1983). The study described here analyses the differences in the portrayal of nurse and physician characters in the three major forms of entertainment media: 
novels, motion pictures, and prime time television. Specifically this comparison is made in order to determine differences in the depiction of nurse and physician characters, demographic characteristics, centrality of role, personality attributes, primary values, and professional behaviours. A secondary purpose is to illuminate changes in the portrayal of nurse and physician characters from 1920 to the present.

\section{METHOD}

\section{Data collection}

Novels, motion pictures, and prime time television programmes for the period 1920 to 1980, with nurse and physician characters in significant roles, constituted the study sample. Novels were identified through a comprehensive examination of book reviews published between 1920 and 1980 in the New York Times Book Review, The Bookman (1920-1933) and Publisher's Weekly (1920-1980). Motion pictures were identified by a review of the cumulative reprints of the New York Times Film Reviews, Variety Weekly Film Reviews, the American Film Institute Catalog of Motion Pictures, and through personal research in public and private film archives. Prime time television series were identified by a review of each weekly issue of $T V$ Guide (New York City edition) published from 1950 to 1980 . A $20 \%$ sample of the episodes was randomly selected from each series identified as appropriate for the study so that the representativeness of any given series in the sample corresponded to its duration on television. The total sample size was made up of 670 nurse characters and 466 physician characters. These characters were divided by media in the following way: 307 in novels, 321 in motion pictures, and 508 in television.

\section{Instruments}

Using the research methodology of content analysis, three instruments were developed and tested for coding the messages about nurses and physicians in the entertainment mass media.
The Unit Analysis Tool contained variables which address dominant impressions of nursing, medicine and health care in a given mass media portrayal. Contained within this tool were items on objective actions of the total group of nurse and physician characters appearing in the entertainment media as well as subjective impressions conveyed by the narrator comment, behaviour of other characters, filming technique, and the situational contexts in which the characters were presented.

The Nurse Character Analysis Tool and the Physician Character Analysis Tool were used to collect data on the portrayals of these characters in each episode. Questions dealt with the extent of the character's role in the episode, objective physical attributes and behaviour of the character as well as the subjective impressions created by context, comment and filming techniques.

\section{Reliability and validity}

Coders underwent a standardized training programme developed for the project. Intrarater reliability was determined by having coders recode a randomly selected sample of media units several months later without access to their original coding sheets. Intra-rater reliability across all coders and all items was $93 \cdot 1 \%$ for motion pictures, $87 \cdot 1 \%$ for novels, and $88.4 \%$ for television. Inter-rater reliability was determined by having all coders analyze a $20 \%$ sample of the units. Inter-rater agreements among all coders was $91.6 \%$ for motion pictures, $88.3 \%$ for novels, and $90.2 \%$ for television.

Content validity was established by an inductive and additive process of classifying all aspects of the image of the nurse and physician which were found to exist in the entertainment mass media until all categories of new phenomena were exhausted. Instruments were then reviewed by a panel of experts and subsequently modified prior to actual data collection.

Convergent validity was estimated by testing the ability of certain measurement items in the data instruments to predict others in an expected or hypothesized fashion. For example, $92 \%$ of units coded as hospital dramas were also coded as showing nurses and physicians 
working in a hospital setting. One-hundred per cent of the nurse characters who stated that nursing constitutes a patriotic service were also coded as appearing in military drama or comedy. It was also found that nurses who were shown in administrative roles were also portrayed as having power and influence over others $(r=0.54, P<0.01)$. There was a significant association between the extent to which nurse characters were seen helping patients and the degree to which they provided emotional support to patients and families $(r=0 \cdot 54$, $P<0.01)$.

Since our purpose was to capture an integrated, composite image of nurse and physician characters, and given the fact that it was easier to deal conceptually and mathematically with a few indices rather than with multiple variables, several different analytic procedures (factor analysis, principal component analysis, etc.) were used to condense variables into a smaller number of factors that would represent statistical parsimony. Each construct reported in this analysis was subjected first to reliability testing via estimation of the extent to which it exhibited internal consistency (Nunnally 1978, Peter 1979). All constructs produced a coefficient alpha of at least 0.69 . Split-half reliability was also estimated by random assignment of items within a given construct to one of two groups followed by canonical correlation between the two sets of measures (Muliak 1972). All constructs were found to exhibit split-half reliability of at least $0.58, P<0.05$. Then each construct was submitted to predictive validity testing to determine the extent to which it corresponded with some external criterion measure logically expected to be related.

\section{RESULTS}

\section{Demographic characteristics}

Media nurses are predominantly female ( $99 \%)$, caucasian $(95.6 \%)$, under 35 years of age $(62 \cdot 5 \%)$, single $(71 \%)$ and childless $(89 \cdot 4 \%)$. This demographic profile of nurse characters projected in the entertainment mass media did not change significantly over the 60 years covered by the study and did not vary significantly by type of media. Media physicians, by contrast, are older $(t(1113)=8.77, P<0.0001)$, more often parents $(t(1129)=3.68, P<0.0001)$ and enjoy a higher socioeconomic status $(t(1108)=$ 15.08, $\quad P<0.0001)$ than nurse characters. Gender difference is the most striking contrast as physicians are overwhelmingly male $(92 \cdot 5 \%)$. As was true with the sample of nurse characters, only $5 \cdot 2 \%$ of physician characters represented minority groups. Nurses are more likely to be of

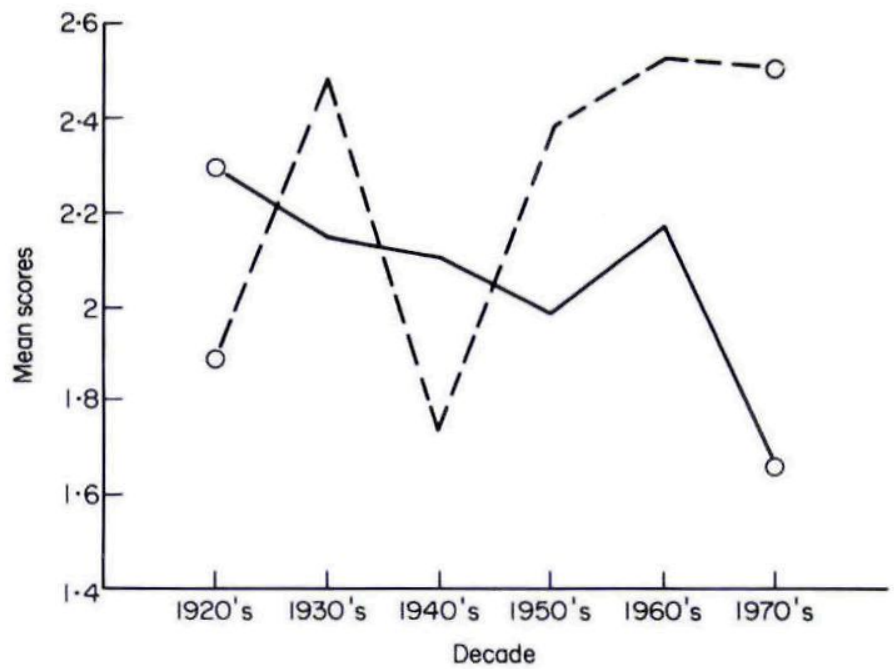

FIGURE 1 Centrality of role of nurse and physician characters in the entertainment media. $\mathrm{O}-\mathrm{O}=$ nurse $: \mathrm{O}-\mathrm{O}=$ physician. 


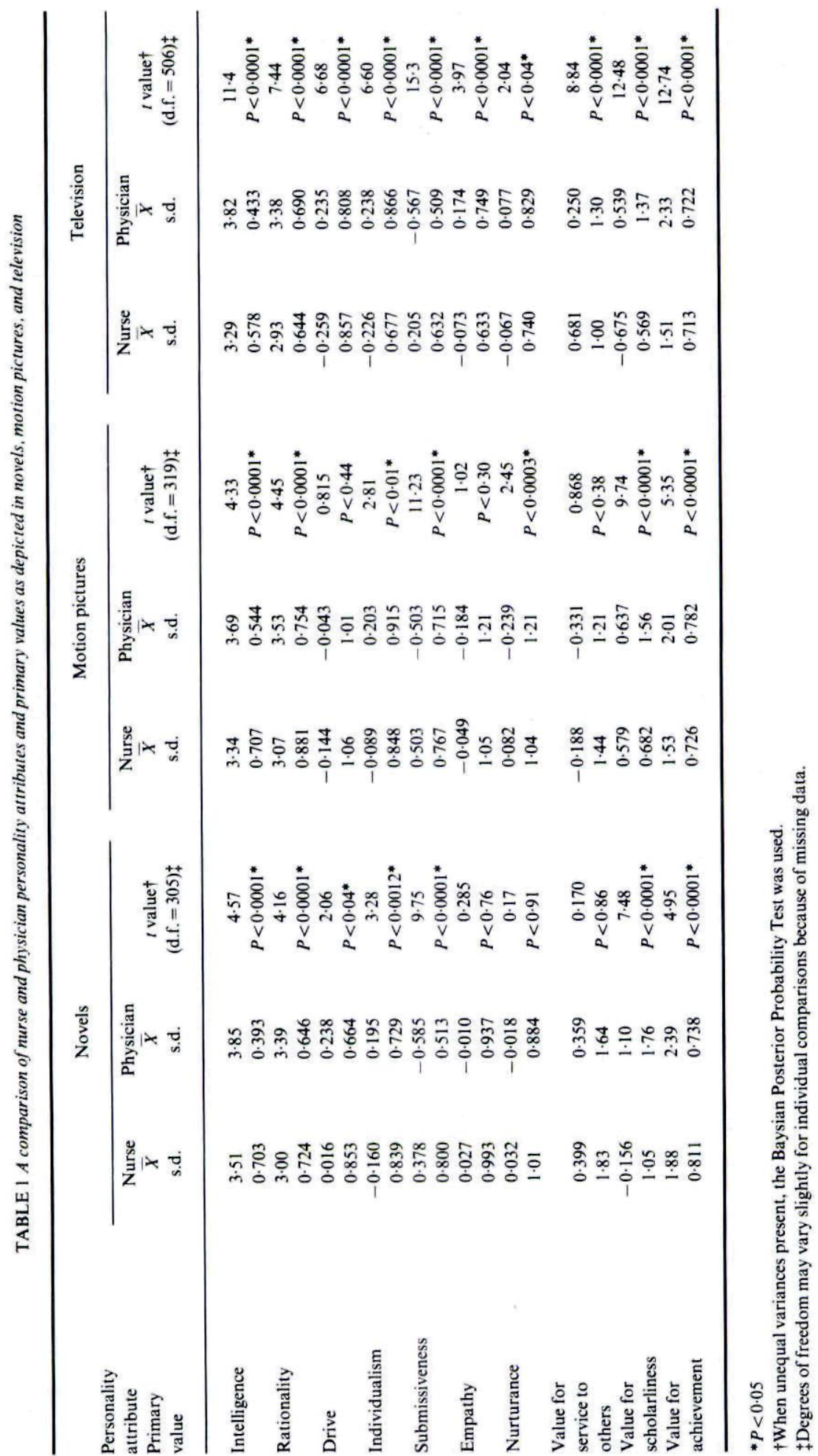


TABLE 2 Correlations between decade and personality attributes and primary values of nurse and physician characters in the entertainment media

\begin{tabular}{|c|c|c|c|c|}
\hline \multirow{2}{*}{$\begin{array}{l}\text { Personality attribute } \\
\text { Primary value }\end{array}$} & \multicolumn{2}{|c|}{ Nurse characters } & \multicolumn{2}{|c|}{ Physician characters } \\
\hline & $r$ & $P$ & $r$ & $P$ \\
\hline Intelligence & -0.174 & $0.0001^{*}$ & 0.013 & 0.7731 \\
\hline Rationality & -0.077 & $0.0502^{*}$ & -0.066 & $0 \cdot 1581$ \\
\hline Drive & -0.157 & $0.0001^{*}$ & 0.021 & 0.6551 \\
\hline Individualism & -0.064 & 0.099 & 0.066 & 0.1541 \\
\hline Submissiveness & -0.134 & $0.0005^{*}$ & -0.024 & 0.6007 \\
\hline Empathy & -0.072 & 0.0629 & $0 \cdot 049$ & 0.2966 \\
\hline Nurturance & $-0 \cdot 103$ & $0 \cdot 0079^{*}$ & 0.060 & 0.1994 \\
\hline Value for service to others & -0.269 & $0.0001^{*}$ & -0.057 & 0.2220 \\
\hline Value for scholarliness & $-0 \cdot 139$ & $0.0003^{*}$ & -0.110 & $0.0178^{*}$ \\
\hline Value for achievement & -0.101 & $0.0086^{*}$ & 0.055 & 0.2332 \\
\hline
\end{tabular}

$* P<0.05$

the Christian religion than physicians $(t(1026)=3 \cdot 41, P<0 \cdot 0001)$.

\section{Centrality of role}

Physician characters are presented as more central to the plot than are nurse characters $(t(1026)=10 \cdot 13, P<0 \cdot 0001)$. In other words, physicians are shown in a greater number of leading roles and engaged in more instrumental behaviour than are nurses. Nurse characters are typically relegated to supporting roles which strongly conveys a somewhat subtle but unmistakable message to the viewer that nurses are not as essential or important in health care. As can be noted in Figure 1, over time, physicians are becoming more central to the dramatizations $(r=0.13, P<0.001)$ and nurses less so $(r=-0.23, P<0.001)$. In other words, the nurse momentarily in the background carrying a tray, pushing a wheelchair or holding a chart has become a media staple, while significant, leading roles for nurses have experienced a steady and alarming decline as female physicians take on more and more of the female roles in the health care genre.

\section{Personality attributes and primary values}

Personality attributes and primary values of media characters offer both overt and covert clues to the public about occupational stereotypes in health care. As can be noted in Table 1, nurse characters are shown to be significantly less intelligent and rational, to exhibit less individualism, and to value scholarliness and achievement less than physician characters across all the types of entertainment media. Media nurses are also portrayed as having less drive than media physicians in two of the three media. In contrast to these characters, nurses score consistently higher than physicians in all three media on only one attribute - submissiveness. Media nurses are also depicted as valuing service and being empathic significantly less than media physicians in the media of television. Furthermore television nurses are less nurturant than television physicians.

Table 2 contains the correlations between decade and personality attributes and primary values. These data present consistent results. Nurse characters have experienced a significant decline from 1920 to 1980 in eight of the ten attributes and values studied, while physician characters on the other hand, have shown no significant changes except for a decline in value for scholarliness. Even the two nurses' attributes and values which did not change significantly - individualism and empathy - show a downward trend.

A comparison of these personality attributes and primary values by each decade for nurse and physician characters revealed that media nurses have always been depicted as more 
submissive and as valuing scholarliness and achievement less than media physicians (Table 2). From 1930 through the 1970 's, nurse characters have also been portrayed as consistently less intelligent and rational. Media nurses have exhibited less individualism since 1940 as well. Differences between nurse and physician empathy and nurturance did not emerge until the 1950's when nurses were depicted as having more of these attributes and then in the 1970's, they were shown to exhibit significantly less of them. Nurse and physician drive and value for service to others were also not significantly different until the 1970's when media nurses exhibited significantly less of these characteristics than media physicians.

\section{Professional behaviours}

As can be noted in Table 4, physician characters are depicted as viewing their career as more important to their lives and as exercising clinical judgement significantly more than nurse characters consistently across all three types of entertainment media. Praise for professional behaviour is higher for physician characters in motion pictures and television. Favourable attitudes are significantly more likely to be expressed toward physician characters than nurse characters in novels and television. And finally, although no differences exist between nurse and physician positive impact on patient welfare in novels and motion pictures, nurses are significantly less likely to be shown helping patients on television.

Over time, nurse characters have shown a significant decline in praise, favourable attitudes, positive impact on patient welfare, and use of clinical judgement (See Table 5). Media physicians have experienced a significant decline in praise and importance of work to life, but they have also been depicted as helping patients significantly more over time.

When nurse and physician characters are compared for each decade, media physicians are consistently found to score higher than media nurses in terms of favourable attitudes expressed toward them (See Table 6). Except for the decade of the twenties, physicians have also been depicted as using clinical judgement more than nurses. Praise was significantly higher for media physicians in both the 1930's and 1970's, while media physicians saw their work as more central to their lives than media nurses in the 1930 's, 1960's, and 1970's. But perhaps the most noteworthy finding is that no differences in helping patients was evident until the most recent decade, when nurses were significantly less likely to be shown having a positive impact on patient welfare (Figure 2).

\section{DISCUSSION}

The findings of this study point to the fact that the contribution of the nurse to health care as portrayed in the entertainment media has been distinctly underplayed, and conversely the role of the physician has been presented in an exaggerated, idealistic, and heroic light. The evidence is substantial. Personality attributes, primary values and professional behaviour associated with media physicians are heavily linked with a 'man of science' image. In other words, physician characters consistently exhibit drive, individualism, rationality and intelligence. They are almost always men who value achievement and scholarship, see their work as central to their life, exhibit strong clinical skills, and are greatly admired by other characters in the dramatizations.

Media nurses, by contrast, lack distinction in all aspects of scientific work, intellectual pursuits and career commitment. Even basic intelligence, rationality, problem-solving abilities and clinical skills are absent in most nurse portrayals. Nurse characters are presented as generally unimportant in health care, largely occupying the background rather than playing an instrumental role in health care. Media nurses are viewed less positively than physicians by other characters, and show little commitment to their careers. The central and diverse role the nurse actually plays in the delivery of health care to the American public is virtually absent in the entertainment media.

Moreover, it is significant to note that nurse characters are shown to be less empathic and to value service to others less than physician characters in the most powerful of all of the entertainment media - television. Since these 


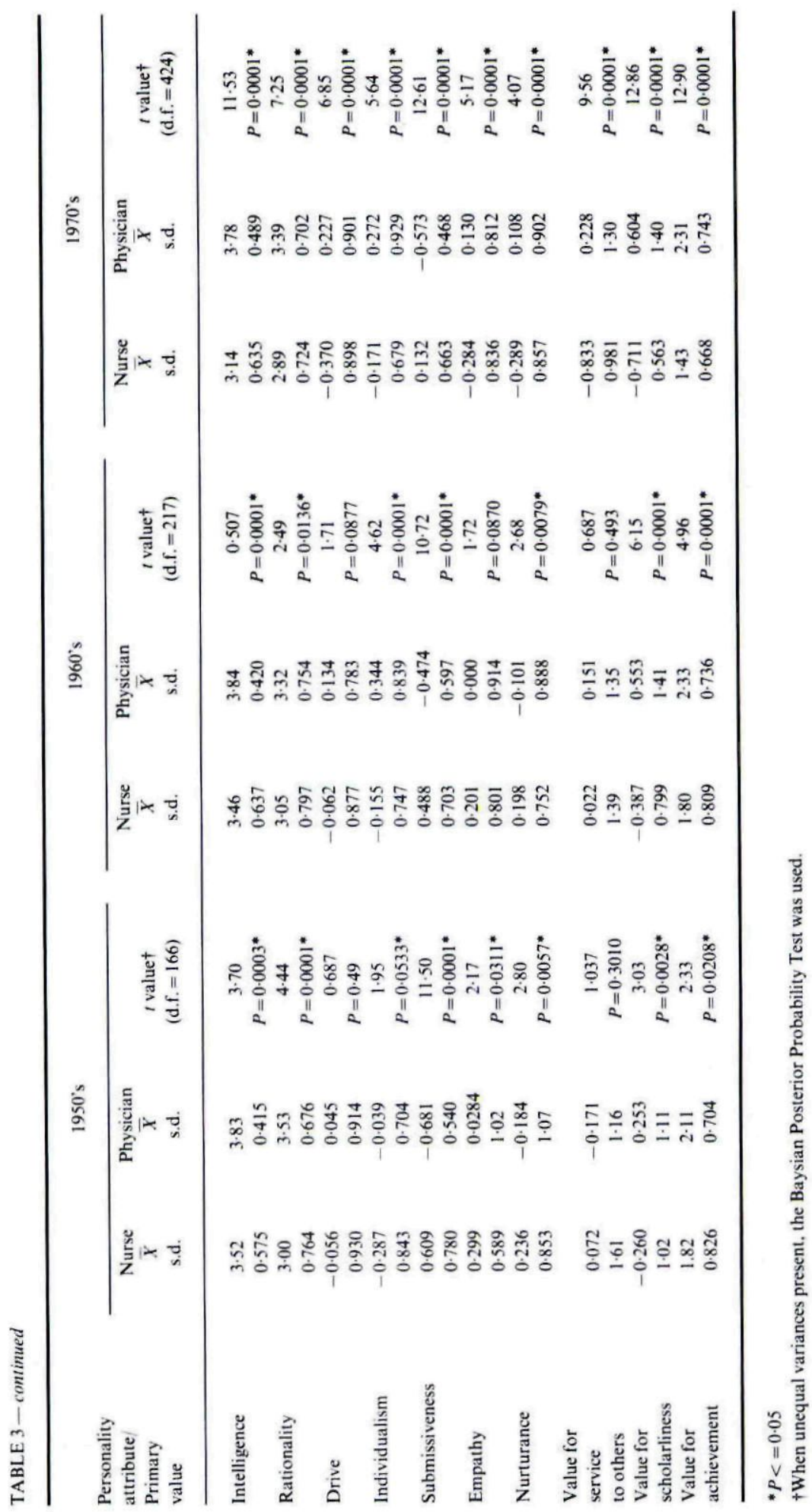




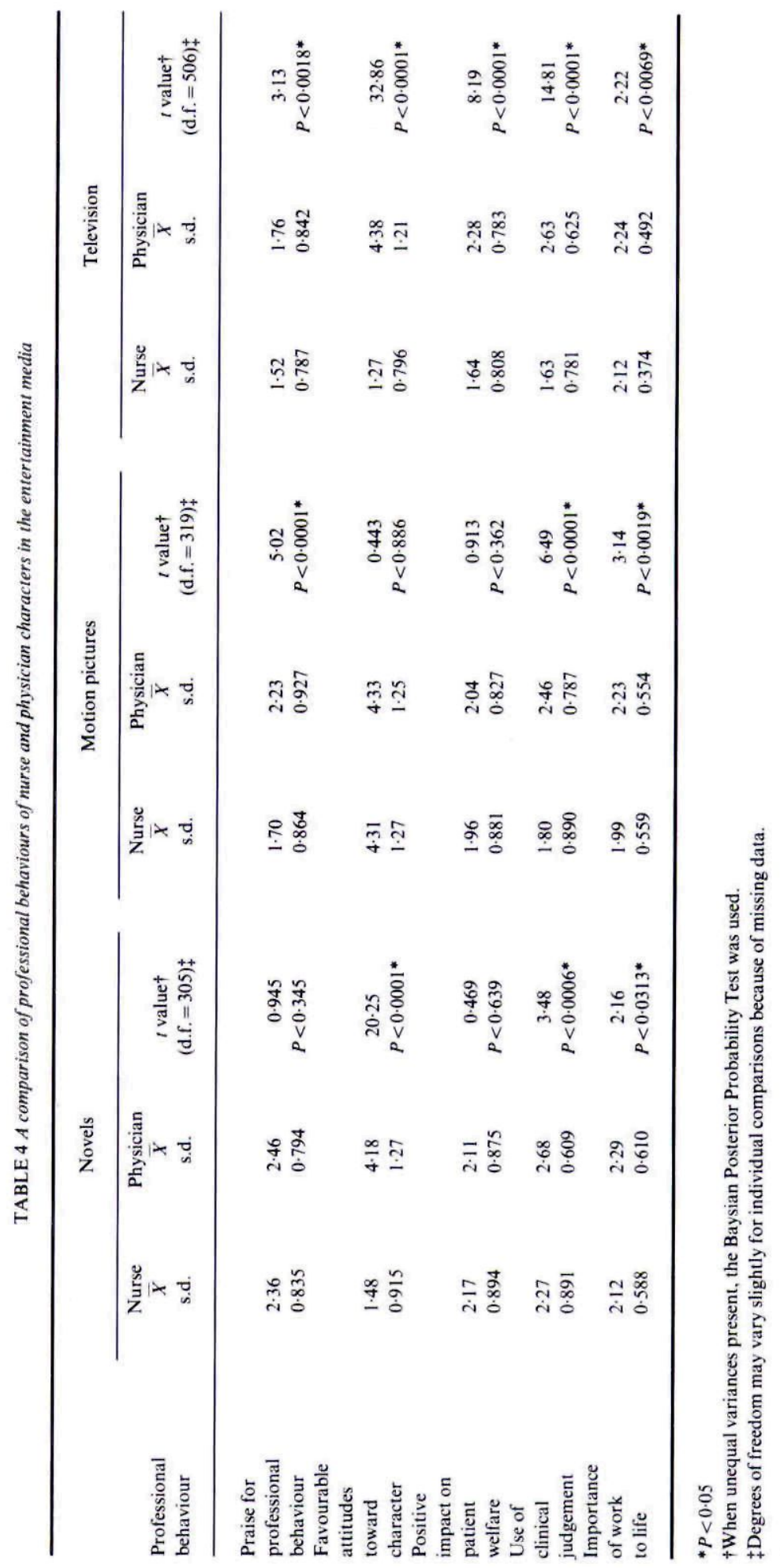


TABLE 5 Correlations between decade and professional behaviours of nurse and physician characters in the entertainment media

\begin{tabular}{lccccc}
\hline & \multicolumn{2}{c}{ Nurse characters } & & \multicolumn{2}{c}{ Physician characters } \\
\cline { 2 - 3 } \cline { 5 - 6 } $\begin{array}{l}\text { Professional } \\
\text { behaviour }\end{array}$ & $r$ & $P$ & & $r$ & $P$ \\
\hline Praise for professional behaviour & -0.214 & $0.0001^{*}$ & & -0.2413 & $0.0001^{*}$ \\
Favourable attitudes toward character & -0.237 & $0.0001^{*}$ & & 0.0175 & 0.7076 \\
Positive impact on patient welfare & -0.099 & $0.0168^{*}$ & & 0.1064 & $0.0254^{*}$ \\
Use of clinical judgement & -0.145 & $0.0004^{*}$ & & 0.0483 & 0.3125 \\
Importance of work to life & -0.016 & 0.724 & & -0.1011 & $0.0418^{*}$ \\
\hline
\end{tabular}

$* P<0.05$

humanistic characteristics have been traditionally associated with the nursing, as opposed to the medical, profession, it is indeed surprising, and quite unfortunate, that nurses fall considerably short of physicians. These findings are coupled with the fact that although nurse and physician characters are shown to be similar in their positive impact on patient welfare in motion pictures and novels, television depicts nurses as significantly less likely to be of help to patients. A similar pattern is seen with other study variables.

In analyzing the meaning of these data, it appears that a set of characteristics that we have labeled the 'Marcus Welby syndrome' appears to be operative in the television health care genre. As epitomized by the television physician character, Marcus Welby, this fictitious health care provider is consistently portrayed as providing both outstanding medical care and nursing care. Welby, for example, was not only shown carrying out surgery, diagnosing illness, determining medical treatment and other medical tasks, but was also shown making home visits, providing virtually all of the emotional support to patients and their families, preparing patients for surgery, carrying out health teaching, supervising the hospital nursing staff, and even providing 24-hour a day surveillance if needed. Although this syndrome has typified the health care genre throughout television's 30 -year history, the phenomena has been most evident in the past decade. It is particularly damaging to the image of the nurse, since the public is led to believe that no special body of nursing knowledge and skill exists and that physicians can step in at any point in time and provide excellent nursing care. This also reinforces the damaging stereotype that nursing is the lower part of the medical profession.

\section{Dominated by the medical voice}

Most of the characterizations of nurses are dominated by what one might call the medical voice. The definition of nurses' most serious problems and the proposed solutions to these problems are really, though often covertly, tailored to meet the needs of fundamentally medical problems. This kind of characterization must be termed stereotyped, because it tends always to emphasize one aspect of character while leaving out others of equal or greater importance. To be more explicit, the bias is carefully chosen so that certain types of physicians' behaviour relative to nurses are justified. The stereotypes of nurses vary, but they vary in response to the needs of physicians. The flattering frequency with which nurses appear in the entertainment media is ultimately deluding: they appear not as they are, certainly not as they would define themselves, but as conveniences to the resolution of physicians' dilemmas.

Perhaps of even greater concern is the consistency in the study findings which point to a steady and unmistakable decline in the image of the nurse over time. With few exceptions, the depiction of nurse characters has declined in terms of positive personality attributes, primary values, and professional behaviours. The most recent decade marks the low point for many of 


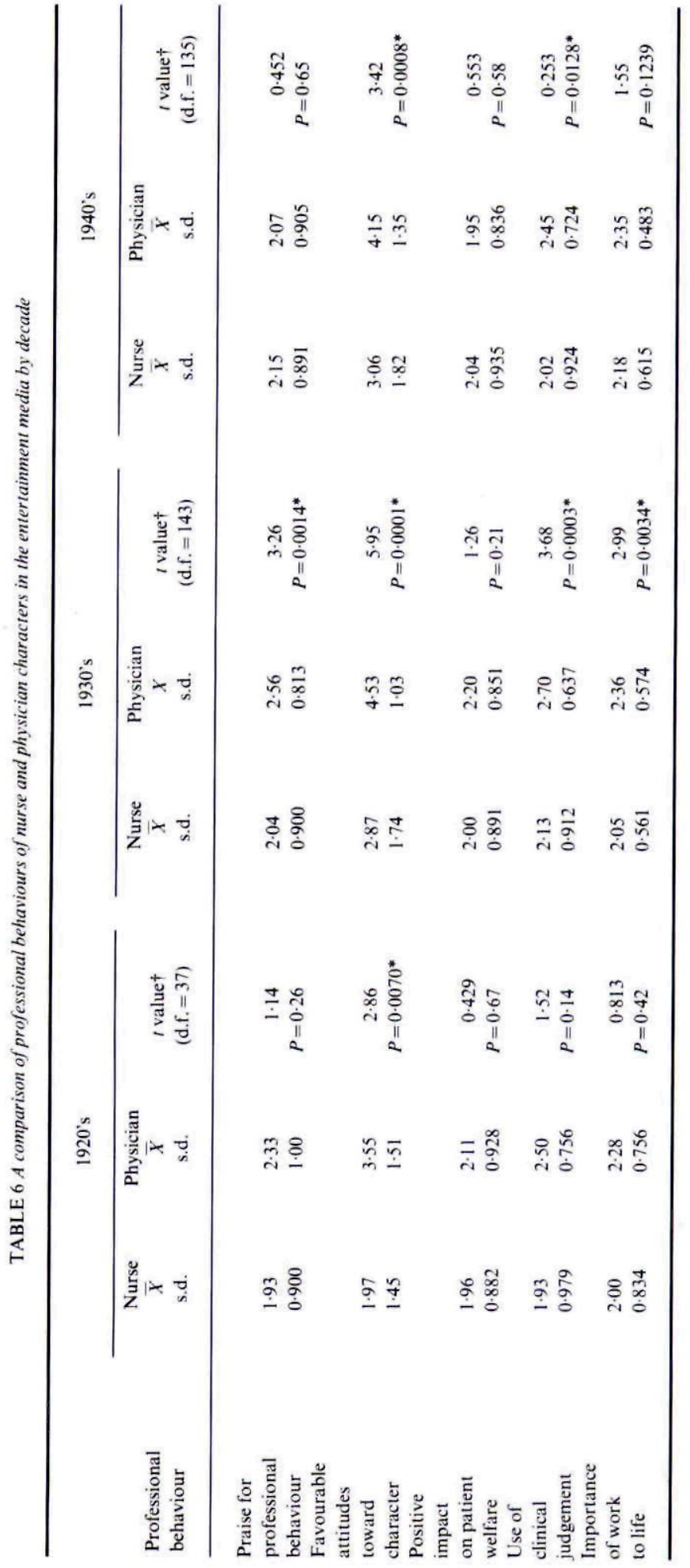




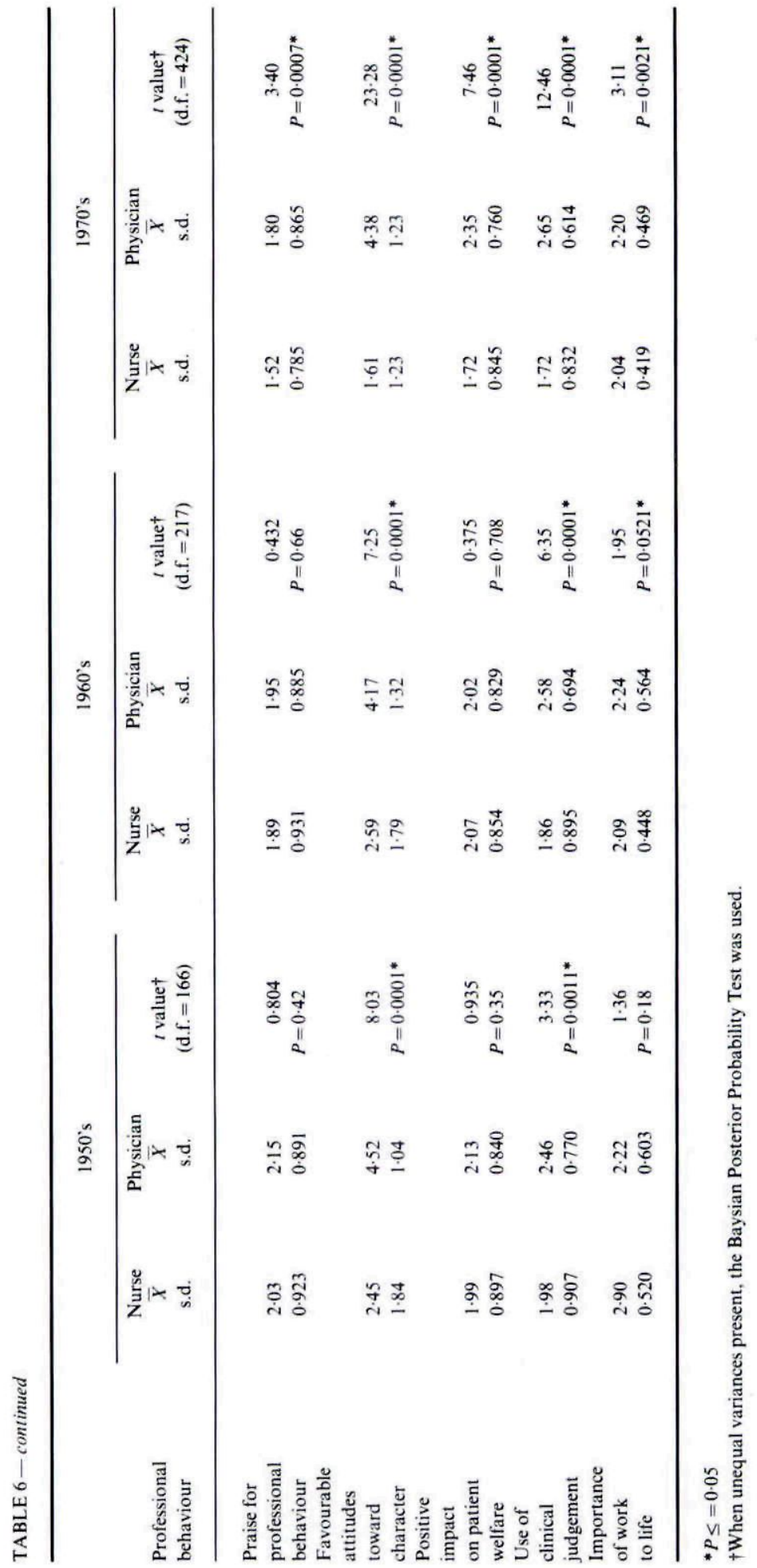




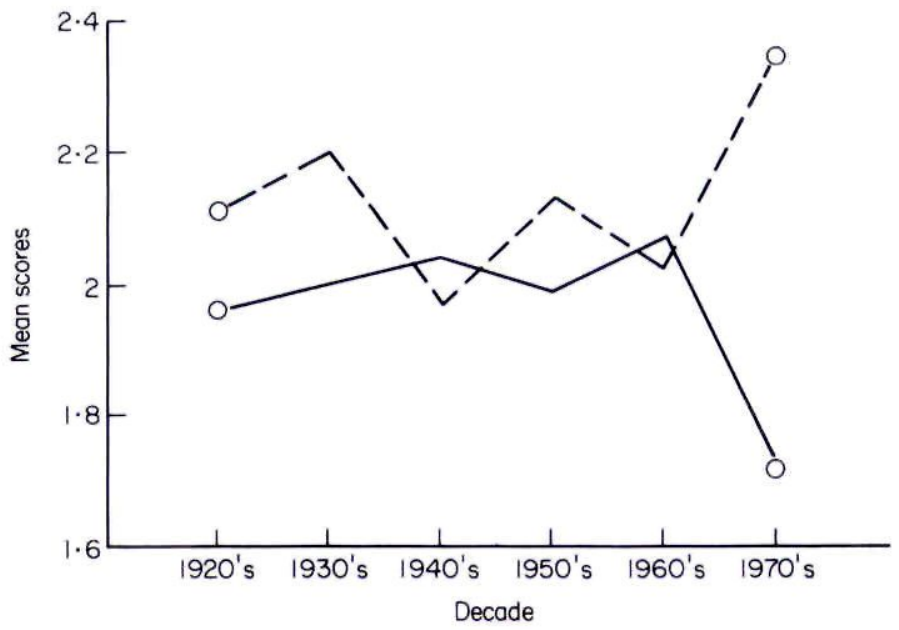

FIGURE 2 Positive impact on patient welfare of nurse and physician in the entertainment media. $\mathrm{O}_{-}=$nurse $; \mathrm{O}_{-}-\mathrm{O}=$ physician .

these characteristics. Physician characters in the entertainment media, by contrast, have virtually remained at high levels for most attributes, values, and behaviours. When a change has occurred for physicians, it has almost always represented a gain in imagery, especially in the humanistic, psychosocial arena of care.

\section{IMPLICATIONS}

The implications of the study findings are farreaching. Today's nurse stereotypes promote negative and wasteful social perceptions of nearly one-half of all health care providers. Current depictions of nurses in the mass media are serving to seriously undermine the potential contribution nurses can make in health care. The public readily distinguishes between characters who are directly associated with positive health care outcomes and those who are not; those who are fairly autonomous problemsolvers and those who are nearly always in dependent roles; those who are usually male and those who are overwhelmingly female.

Not only do these stereotypes influence how consumers view nurses and the extent to which they utilize services nurses offer, but they also impact the images nurses hold of themselves. In other words, when a society gives its sanction, even its praise, to stereotyped images of nurses, the nurses who work in that culture form their own self-images accordingly. Stereotypes may become, by a sort of perversity, an image of reality that even nurses seek to perpetuate. When nurses are constantly portrayed in negatively stereotyped ways, these images affect their lives and their aspirations as well as delimiting the scope of their work.

Related to this fact is that authors, producers, directors and scriptwriters may actually avoid the notion that the current nurse image may be stereotyping and demeaning, and that other approaches could work as well or better, because the current approach is ultimately a reinforcement of their own prejudices. To change the method would need a counterchange, a reformation of their own attitudes which would be cognitively discomforting. The mass media industries more than any others have the opportunity to reaffirm these images continually by portraying the well-taught nurse, like the original Uncle Tom, trustingly responding in the way she now knows; in fact, only knows. The mass media acts as a moulder of outlook and fosters a legitimization of those roles in which nurses are depicted. The role, the life patterns indicated, the stances adopted, are all consistent in their occurrence and their form and are, it must be remembered, cumulative.

The particular assumptions in mass media communications about the division of health care responsibilities between nurses and 
physicians have an important impact on the interests of the members of both professions. These interests are not always entirely coincident. The fact that certain values favouring the interests of physicians rather than nurses have been embodied positively in a variety of mass media products indicates that the components of the traditional health care genre are a very important means by which these values, and hence major inequalities between medicine and nursing, are maintained. That these assumptions do not always have to be made explicit suggests that one is looking at the outcome of a powerful set of ideologies concerning nurses and physicians and that mass media messages are one of the means by which these ideologies are sustained.

Given the time-lagged effect of image reshaping efforts, the present is not too soon to begin to educate various publics about the realities of nursing, if we are to have an adequate supply of qualified nurses to meet the health needs of the American public in future decades. In fact, understanding what image power is, how it is acquired, how it can be lost and how it affects resource allocation decisions could well determine whether nursing will move forward or be left behind in the coming decade.

The mass media, by means of its own qualities and colourations, can transform identifiable groups such as nurses and physicians into 'smaller than life' or 'bigger than life'. It may act as both a mirror and a lamp. Not only may it reflect the 'reality' of professional contributions, but it may also light the way to new contributions. It is essential for the future of health care in this nation that the mass media begin to light the way for nurses and nursing even if this does require a diminishment of the intensity of the halo that the media physician has worn in recent decades.

\section{References}

Abel J., Fontes B., Greenberg B. \& Atkin C. (1981) The impact of television on children's occupational role learning. Unpublished report, Michigan State University, East Lansing. Michigan.

Arenstein H.L. (1974) The effect of television on children's stereotyping of occupational roles. Unpublished master's thesis, Annenberg School of Communications, University of Pennsylvania.

Aronoff C. (1974) Old age in prime time. Journal of Communication 24, $86-87$
Atkin C. (1978) Effects of drug commercials on young viewers. Journal of Communication 28, 71-79.

Barris A. (1976) Stop the Presses: The Newspaperman in American Films. A.S. Barnes, New York.

Bataille G. \& Silet C. (1980) The Pretend Indians. The Iowa State University Press, Ames, Iowa

Belson W. (1978) Television Violence and the Adolescent Boy. Saxon House, London.

Boulding E. (1956) The Image: Knowledge in Life and Society. University of Michigan Press, Ann Arbor.

Breed W. \& DeFoe J.R. (1981) The portrayal of the drinking process on prime-time television. Journal of Communication $31,58-67$.

Bryan J.H. (1975) Children's cooperation and helping behaviour. In Review of Child Development Research (Hetherington E.M. ed.). University of Chicago Press, Chicago.

Bryant J., Carveth R. \& Brown D. (1981) Television viewing and anxiety: An experimental examination. Journal of Communication 31, 106-119.

Busby L. (1974) Defining the sex role standard in commercial network television programs directed toward children. Journalism Quarterly 51, 690-696.

Cameron A. (1973) The image of the physician in the American novel. 1859-1925. Dissertation Abstracts International 33, 11

Caron A. \& Ward S. (1975) Gift decision by kids and parents. Journal of Advertising Research 15, 12-20.

Cassata M. Anderson P. \& Skill J. (1980) The older adult in daytime serial drama. Journal of Communication 30, 48-49.

Ceccio J. (1978) Medicine in Literature. Longman, New York.

Churchill G. \& Moschis G. (1979) Television and interpersonal influences on adolescent consumer learning. Journal of Consumer Research 6, 23-35

Coates B., Pusser H.E. \& Goodman I. (1976) The influence of 'Sesame Street' and 'Mister Rogers' Neighborhood' on children's social behaviour in the pre-school. Child Development 47, 138-144

Cousins N. (1982) The Physician in Literature. Saunders, Philadelphia

Cripps T. (1977) Slow Fade to Black: The Negro in American Films, 1900-1942. Oxford University Press. New York

De Bakey L. (1964) The physician-scientist as character in nineteenth century American literature. Dissertation Abstracts International 24, 8

Dominick J. \& Greenberg B. (1970) Three seasons of blacks on television. Journal of Advertising Research 10, 21-27.

Donohue T. (1975) Effects of commercials on black children. Journal of Advertising Research 15, 41-46.

Drabman R.S. \& Thomas M.H. (1974) Does media violence increase children's toleration of real-life aggression? Developmental Psychology 10,418-421.

Elliott R. \& Vasta R. (1970) The modeling of sharing: effects associated with vicarious reinforcement, symbolization, age, and generalization. Journal of Experimental Child Psychology 10, 8-15.

Eron L.D. \& Huesmann L.R. (1980a) Adolescent aggression and television. Annals of the New York Academy of Sciences 347, 319-331.

Eron L.D. \& Huesmann L.R. (1980b) Integrating field and laboratory investigations of televised violence and aggression. Paper presented at the meeting of the American Psychological Association, Montreal, Canada, 1980.

Feingold P.C. \& Knapp M.L. (1977) Anti-drug abuse commercials. Journal of Communication 27, 20-28.

Fisher D. \& Dean D. (1976) The realism of marital and parental roles on television. Unpublished report, St. Lawrence University, Canton, New York.

Friedrich L.K. \& Stein A.H. (1973) Aggressive and pro-social television programs and the natural behavior of preschool children. Monographs of the Society for Research in Child Development 38, 1 - 64 . 
Friedrich L.K. \& Stein A.H. (1975) Pro-social television and young children. The effects of verbal labelling and role playing on learning and behavior. Child Development 46, 27-38.

Friedrich-Cofer L.K., Huston-Stein A., Kipnis D.N., Susman E.J. \& Clewett A.S. (1979) Environmental enhancement of prosocial television content: effects on interpersonal behavior, imaginative play, and self-regulation in a natural setting. Developmental Psychology 15, 637-646.

Galst J. \& White M. (1976) The unhealthy persuader: the reinforcing value of television and children's purchaseinfluencing attempts at the supermarket. Child Development 47, 1089-1096.

Gerbner G. (1964) Mass communications and popular conceptions of education: a cross-cultural study. (Cooperative Research Project Technical Report, No. 876.) Department of HEW, Office of Education, Washington, DC.

Gerbner G., Gross L., Jackson-Beeck, M., Jeffries-Fox S. \& Signorielli N. (1978) Violence Profile No. 9: Trends in Network Television Drama and Viewer Conceptions of Social Reality 1967-1977. Annenberg School of Communications, University of Pennsylvania.

Gerbner G., Gross L., Signorielli N., Morgan M. \& JacksonBeeck M. (1979) Violence Profile No. 10: Trends in Network Television Drama and Viewer Conceptions of Social Reality 1967-1978. Annenberg School of Communications, University of Pennsylvania.

Gerbner G., Morgan M. \& Signorielli N. (1982) Programming health portrayals: what viewers see, say, and do. In Television and Behavior: Ten Years of Scientific Progress and Implications for the Eighties (Pearl D., Bouthilet L. \& Lazar J. eds), US Government Printing Office, Washington, DC.

Goldberg M. \& Gorn G. (1978) Some unintended consequences of TV advertising to children. Journal of Consumer Research 5, 22-29.

Gorn G.J., Goldberg M.E. \& Kanungo R.N. (1976) The role of educational television in changing the intergroup attitudes of children. Child Development 47, 277-280.

Granszberg G. \& Steinberg K. (1980) Television and the Canadian Indian (Technical report). Department of Anthropology, University of Winnipeg.

Greenberg N. (1972) Children's reactions to TV blacks. Journalism Quarterly 49, 5-14.

Greenberg B.S. (1975) British children and televised violence. Public Opinion Quarterly 38, 531-547.

Greenberg B., Buerkel-Rothfuss N., Neuendorf K. \& Atkin C. (1980) Three seasons of television family role interactions. In Life on Television (Greenberg B.S. ed.) Ablex Press, Norwood, New Jersey.

Greenberg B.S., Fernandez-Collado C., Graef D., Korzenny F. \& Adkin C.K. (1980) Trends in the use of alcohol and other substances on television. In Life on Television (Greenberg B.S. ed.), Ablex Press, Norwood, New Jersey.

Harris A. \& Feinberg J. (1977) Television and ageing: is what you see what you get? Gerontologist 17, 464468 .

Hartnagel T.F., Teevan J.J. Jr. \& McIntyre J.J. (1975) Television violence and violent behavior. Social Forces 54, 341-351.

Haskell M. (1973) From Reverence to Rape: The Treatment of Women in the Movies. Coward, McCann, and Geoghegan. New York.

Henderson L. \& Greenberg B.S. (1980) Life on Television. Ablex Press, Norwood, New Jersey.

Himmelweit H.T. \& Bell N. (1980) Television as a sphere of influence on the child's learning about sexuality. In Childhood Sexual Learning: The Unwritten Curriculum (Roberts E.J. ed.), Ballinger, Cambridge, Massachusetts.

Huesmann L.R., Eron L.D., Klein R., Briece P. \& Fischer P. (1981) Mitigating the Imitation of Aggressive Behavior. (Technical Report.) Department of Psychology, University of Illinois, Urbana, Illinois.

Jeffries-Fox S. \& Signorielli N. (1978) Television and children's conceptions of occupations. Paper presented at the Airlie House Telecommunications Conference, Warrentown, Virginia.

Johnson F., Davis L. \& McNamee S. (1978) Familial relationships, topics, and conversation styles in family interactions on television in the USA. Unpublished report, University of Massachusetts, Amherst, Massachusetts.

Kalisch P. \& Kalisch B. (1981) The image of psychiatric nurses in motion pictures. Perspective in Psychiatric Care 19, $116-129$.

Kalisch P. \& Kalisch B. (1982) The nurse-detective in American film. Nursing and Health Care 3, 146-153.

Kalisch P. \& Kalisch B. (1983) An analysis of the impact of authorship on the image of the nurse presented in novels. Research in Nursing and Health 6, 17-24.

Kalisch P., Kalisch B. \& Clinton J. (1982) World of nursing on prime time television, 1950-1980. Nursing Research 21, 358-363.

Kalisch B., Kalisch P. \& McHugh M. (1980) Content analysis of film stereotypes of nurses. International Journal of Women's Studies 3, 531-558.

Kalisch B., Kalisch P. \& McHugh M. (1982) The nurse as a sex object in motion pictures, 1930-1980. Research in Nursing and Health 5, 147-154

Kalisch B., Kalisch P. \& Scobey M. (1981) Reflections on a television image: the nurses, 1962-1965. Nursing and Health Care 2, 248-255.

Kalisch P., Kalisch B. \& Scobey M. (1983) Images of Nurses on Television. Springer, New York.

Kaufman L. (1980) Prime-time nutrition. Journal of Communication 3, 37-46.

King D.L. (1979) Conditioning: An Image Approach. Halsted, New York.

Kubey R.W. (1980) Television and ageing: past, present, and future. Gerontologist 20, 16-35.

Lemon J. (1977) Women and blacks on prime-time television. Journal of Communication 27, 70-74.

Long M. \& Simon R. (1974) The roles and statuses of women and children on family TV programs. Journalism Quarterly 51, 107-110.

Loye D., Gorney R. \& Steele G. (1977) Effects of television: an experimental study. Journal of Communication 27, 206-216.

Mapp C. (1970) The portrayal of the Negro in American motion pictures, 1962-1968. Doctoral dissertation, New York University, Dissertation Abstracts International 31, 1929A-3092A.

McCarthy E.D., Langner T.S., Gersten J.C., Eisenberg J.G. \& Orzeck L. (1975) Violence and behavior disorders. Journal of Communication 25, 71-85.

McLaughlin J. (1975a) Characteristics and symbolic functions of fictional televised medical professional and their effect on children. Unpublished master's thesis, Annenberg School of Communications, University of Pennsylvania.

McLaughlin J. (1975b) The doctor shows. Journal of Communications 25, 182-184.

Meyer T. (1976) Impact of 'All in the Family' on children. Journal of Broadcasting 20, 23-33.

Milavsky J., Pekowsky B. \& Stipp H. (1975) TV drug advertising and proprietary and illicit drug use among teenage boys. Public Opinion Quarterly 39, 457-481.

Miller M. \& Reeves B. (1976) Dramatic TV content and children's sex-role stereotypes. Journal of Broadcasting 20, $35-50$.

Moschis G. \& Churchill G. (1978) Consumer socialization: a theoretical and empirical analysis. Journal of Marketing 15, 599609.

Muliak S.A. (1972) The Foundations of Factor Analysis. McGraw-Hill, New York.

Nichols J.M. (1977) Images, Perception and Knowledge. Kluwer. Boston.

Norris C.B. (1970) The image of the physician in modern 
American Literature. Doctoral dissertation, University of Maryland. Dissertation Abstracts International 31,2A.

Northcott H., Seggar J. \& Hinton J. (1975) Trends in TV portrayal of blacks and women. Journalism Quarterly 52, $741-744$.

Nunnally J. (1978) Psychometric Theory (2nd edn). McGrawHill. New York.

Peter J. (1979) Reliability: a review of psychometric basics and percent marketing practices. Journal of Marketing Research 16, 6-17.

Peterson M. (1973) The visibility and image of old people on television. Journalism Quarterly 50, 569-575.

Pettit A. (1980) Images of the Mexican American in Fiction and Film. Texas A \& M University Press, College Station, Texas.

Robertson T., Rossiter J. \& Gleason T. (1979) Children's receptivity to proprietary medicine advertising. Journal of Consumer Research 6, 247-255.

Rosen M. (1973) Popcorn Venus: Women, Movies and the American Dream. Coward, McCann and Geoghegan, New York.

Rushton J.P. \& Owen D. (1975) Immediate and delayed effects of TV modelling and preaching on children's generosity. British Journal of Social and Clinical Psychology 14, 309-310.

Seggar J. (1975) Imagery of women in television drama. Journal of Broadcasting 19,273-282.

Seggar J. \& Wheeler P. (1973) World of work on TV: ethnic and sex representation in TV drama. Journal of Broadcasting 17, 201-214.

Shinar D. \& Biber A. (1978) Images of aging among specific groups: the theatre as a research framework. Paper presented at the meeting of the International Gerontological Society, Jerusalem, 1978.

Shorr J., Sobel B., Robin P. \& Coppella J. (1980) Imagery: Its Many Dimensions and Applications. Plenum, New York.

Silverman L.T., Sprafkin J.N. \& Rubinstein E.A. (1979) Physical contact and sexual behavior on prime-time TV. Journal of Communication 29, $33-43$.

Silvetter H. (1967) The Doctor on Stage. University of Tennessee Press, Knoxville.

Singer J.L. \& Singer D.G. (1980) Television, Imagination and Aggression: A Study of Preschoolers' Play. Erlbaum. Hillsdale, New Jersey.
Sprafkin J.M.. Lieberg R.M. \& Poulos R.W. (1975) Effects of a prosocial example on children's helping. Journal of Experimental Child Psychology 20, 119-126.

Stoddard K. (1980) The image of the aging woman in American popular film. Doctoral dissertation. University of Maryland, 1980. Dissertation Abstracts International 41, 2328A-2801A.

Surlin S. (1978) 'Roots' research: a summary of findings. Journal of Broadcasting 22, 309-320.

Surlin S. \& Tate E. (1976) All in the family: is Archie funny? Journal of Communication 26, 61-68

Thomas M.H. \& Drabman R.S. (1975) Toleration of real life aggression as a function of exposure to televised violence and age of subject. Merrill-Palmer Quarterly 21, 227-232.

Tower R. B., Singer D.G., Singer J.L. \& Biggs A. (1979) Differential effects of television programming on pre-schoolers cognition. imagination, and social play. American Journal of Orthopsychiatry 49, 265-281.

Trautmann J. (1981) Healing Arts in Dialogue: Medicine and Literature. Southern Illinois University Press, Carbondale. Illinois.

Volgy T.J. \& Schwartz J.E. (1980) TV entertainment programming and sociopolitical attitudes. Journalism Quarterly 57, $150-155$.

Ward S., Wackman D. \& Wartella E. (1977) How Children Learn to Buy: The Development of Consumer Information Processing Skills. Sage, Beverly Hills, California.

White M.A. \& Sandberg B. (1980) The television prime-time diet. Paper presented at the meeting of the American Psychological Association, Montreal, Canada, 1980.

Williams F., LaRose R. \& Frost F. (1981) Children, Television and Sex-Role Stereotyping. Praeger, New York.

Williams T.M. (1978) Differential impact of TV on children: A natural experiment in communities with and without TV. Paper presented at the meeting of the International Society for Research on Aggression, Washington, DC, 1978.

Worden J. (1962) The portrayal of the protestant minister in American motion pictures, 1951-1960, and its implications for the church today. Doctoral dissertation, Boston University, 1962. Dissertation Abstracts 23, 1137-1464.

Yates G.C.R. (1974) Influence of televised modeling and verbalization on children's delay of gratification. Journal of Experimental Child Psychology 18, 333-399. 
This document is a scanned copy of a printed document. No warranty is given about the accuracy of the copy. Users should refer to the original published version of the material. 